\title{
Methodologies for calculating FRAND damages: an economic and comparative analysis of the case law from China, the European Union, India, and the United States
}

\author{
Anne Layne-Farrar ${ }^{1,2}$ - Koren W. Wong-Ervin ${ }^{3}$
}

Published online: 14 September 2017

(C) The Author(s) 2017. This article is an open access publication

\begin{abstract}
In the last several years, courts around the world, including in China, the European Union, India, and the United States, have ruled on appropriate methodologies for calculating either a reasonable royalty rate or reasonable royalty damages on standard-essential patents (SEPs) upon which a patent holder has made an assurance to license on fair, reasonable and non-discriminatory (FRAND) terms. Included in these decisions are determinations about patent holdup, licensee holdout, the seeking of injunctive relief, royalty stacking, the incremental value rule, reliance on comparable licenses, the appropriate revenue base for royalty calculations, and the use of worldwide portfolio licensing. This article provides an economic and comparative analysis of the case law to date, including the landmark 2013 FRAND-royalty determination issued by the Shenzhen Intermediate People's Court (and affirmed by the Guangdong Province High People's Court) in Huaweiv. InterDigital; numerous U.S. district court decisions; recent seminal decisions from the United States Court of Appeals for the Federal Circuit in Ericsson v. D-Link and CISCO v. CSIRO; the six recent decisions involving Ericsson issued by the Delhi
\end{abstract}

Anne Layne-Farrar-Vice President, Adjunct Professor; Koren W. Wong-Ervin-Director, Adjunct Professor of Law.

The GAI receives funding from entities that may have an interest in the subject matter of this article.

Koren W. Wong-Ervin

kwongerv@gmu.edu

Anne Layne-Farrar

ALayne-Ferrar@crai.com

1 Antitrust and Competition Economics Practice, Charles River Associates (CRA), Chicago, IL, USA

2 Northwestern School of Law, Chicago, IL, USA

3 Global Antitrust Institute (GAI), Scalia Law School, George Mason University, Arlington, VA 22201, USA 
High Court; the European Court of Justice decision in Huawei v. ZTE; and numerous post-Huawei v. ZTE decisions by European Union member states. While this article focuses on court decisions, discussions of the various agency decisions from around the world are also included throughout.

Keywords Standard Essential Patents · FRAND - Damages · Comparative

\section{Introduction}

In the last several years, courts around the world, including in China, the European Union, India, and the United States, have ruled on appropriate methodologies for calculating either a reasonable royalty rate or reasonable royalty damages on standard-essential patents (SEPs), upon which a patent holder has made an assurance to license on fair, reasonable and non-discriminatory (FRAND) terms. ${ }^{1}$ Included in these decisions are determinations about patent holdup, licensee holdout, royalty stacking, the incremental value rule, reliance on comparable licenses, the appropriate revenue base for royalty calculations, and the use of worldwide portfolio licensing. This article provides an economic and comparative analysis of the case law to date, including:

- the first-ever court FRAND-royalty determination issued by the Shenzhen Intermediate People's Court in 2013 (and affirmed by the Guangdong Province High People's Court) in China in Huawei v. InterDigital;

- the numerous U.S. district court decisions providing guidance on methodologies for calculating RAND royalties or damages, including Judge Robart in Microsoft v. Motorola, Judge Holderman in In re Innovatio IP Ventures, Judge Davis in Ericsson v. D-Link, Wi-Lan v. Alcatel-Lucent, and CSIRO v. Cisco, Judge Whyte in Realtek v. LSI; Judge Koh in GPNE v. Apple, and Magistrate Judge Grewal in Golden Bridge Techn. v. Apple.;

- recent seminal decisions from the United States Court of Appeals for the Federal Circuit, namely Ericsson v. D-Link and CISCO v. CSIRO, providing guidance to lower courts on how to calculate RAND damages, including the evidentiary requirements for considering alleged concerns about patent holdup and royalty stacking, the use of comparable licenses, and the "smallest salable patent practice unit" (SSPPU) approach;

- recent decisions from the Delhi High Court granting Ericsson's requests for interim injunctive relief on its FRAND-assured SEPs and upholding the company's practices of licensing on a portfolio end-user device level;

- the 2015 European Court of Justice decision on injunctive relief in Huawei $v$. $Z T E$; and

\footnotetext{
1 For the purposes of this article, we use the terms "FRAND" and "RAND" interchangeably. While the latter is more commonly used in the United States and the former more commonly used throughout the rest of the world, the terms have been largely treated as synonymous.
} 
- the numerous cases from European Union member states addressing issues such as whether offering worldwide portfolio licenses is consistent with FRANDassurances.

While these rulings exhibit a number of differences, some common principles have emerged as well:

- FRAND royalties must provide the patent holder with reasonable compensation;

- in determining a FRAND royalty rate, courts should consider comparable licenses, including licenses calculated based on the end-user device;

- concerns about patent holdup must be symmetrical, i.e., if courts consider holdup by patent holders, then they should also consider holdup and holdout by implementers.

The remainder of this article is organized as follows. Section 2 focuses on how courts have considered concerns about holdup, holdout, and royalty stacking. Sections 3 and 4 discuss licensing benchmarks and methods for determining FRAND terms in litigation, ${ }^{2}$ including the SSPPU approach and reliance on comparable licenses; Sect. 5 covers court decisions upholding the use of worldwide portfolio licensing as consistent with FRAND-assurances; and Sect. 6 concludes. While this article focuses on court decisions, discussions of the various agency decisions from around the world are also included throughout.

\section{Holdup, holdout, and royalty stacking}

"Patent holdup" by a patent holder refers to the potential problem that arises when a SEP holder has made an assurance to license on FRAND terms but then seeks to use standard-lock-in to obtain a supra-FRAND rate. ${ }^{3}$ On the other side of the transaction, innovators that are contributing to a standard-development organization (SDO) can also be locked-in, and hence susceptible to licensee holdup or holdout, if the contributed technologies have a market only within the standard. Thus, incentives to engage in holdup can run in both directions. ${ }^{4}$ While holdup by implementers (sometimes referred to as "reverse holdup") refers to the situation in which a licensee uses its leverage to obtain rates and terms below FRAND levels, holdout refers to a licensee either refusing to take a FRAND license or unreasonably

\footnotetext{
${ }^{2}$ Note that FRAND determinations in litigation settings are distinct exercises from negotiating FRAND terms and conditions in arm's length bargaining. In the latter, business people discuss the value exchange, whereas in the former not only are the parties not willing to bargain, they must rely on whatever evidence can be readily extracted from available documents and testimony.

3 In our opinion, a FRAND rate may properly include some of the value the patented technology receives from incorporation into a standard, particularly given that a standard will reflect the joint value contributed by all active participants and as such should be shared among all contributors.

4 Douglas H. Ginsburg et al., The Troubling Use of Antitrust to Regulate FRAND Licensing, COMPETITION Pol'y Int'l ANTITRUst Chron. at 2 (Oct. 2015), http://papers.ssrn.com/sol3/papers.cfm?abstract_id $=2674759$ [hereinafter Ginsburg et al.].
} 
delaying doing so. The royalty stacking theory, which is based on the Cournot complements problem, maintains that patent holders will set their royalty rates without regard to the other strictly complementary patent holders, potentially leading to an "excessive" cumulative royalty payment, which we define as a royalty for the good's producer that is so high that it cripples the product market, or at a minimum severely restricts output.

\subsection{Court rulings}

Courts in the European Union, India, and the United States have recognized that holdup may be practiced by either SEP holders or implementers, and have explained the critical importance of ensuring a balance between the two interests in developing legal rules governing SEPs. ${ }^{5}$

In the United States, prior to the seminal decision by the U.S. Court of Appeals for the Federal Circuit (which has nationwide jurisdiction over patent law) in Ericsson v. D-Link, ${ }^{6}$ lower courts were divided on whether theoretical concerns about holdup and royalty stacking must be taken into consideration when assessing or determining rates as RAND, or whether they must be proven with evidence. ${ }^{7}$ One approach had been to estimate the potential aggregate royalty burden by assuming that all SEP holders would charge the same rate as that offered by the accused SEP holder. ${ }^{8}$ For example, since Motorola sought a royalty rate of $2.25 \%$ of end user device prices, the court in Microsoft $v$. Motorola multiplied a discounted rate of $1.15-1.73 \%$ (discounted for theoretical cross-licenses between Microsoft and Motorola) by the number of SEP holders to estimate royalty stacking.

The Federal Circuit in Ericsson rejected the theoretical approach taken in the Microsoft case and by some other U.S. lower courts, which did not require implementers to show what royalties they were actually currently paying to other SEP holders. Under the Federal Circuit's decision, the actual cumulative royalty paid by a particular implementer must be proven and assessed to determine whether it is excessive. Reiterating this criterion in CSIRO v. Cisco, the Federal Circuit stated that "abstract recitations of royalty stacking theory, and qualitative testimony

\footnotetext{
5 See, e.g., Case C-170/13, Huawei Technologies Co. v. ZTE Corp. $\mid 65$ (July 16, 2015) (recognizing concerns about reverse-holdup, stating that the Court will not tolerate infringers" "delaying tactics"), http://curia.europa.eu/juris/document/document.jsf?text=\&docid=165911\&pageIndex=0\&doclang=EN\& mode $=1$ st \&dir $=\& o c c=$ first \&part=1\&cid=603775; id. 55 (stating that it is essential "to ensure a fair balance between the interests concerned"); Telefonaktiebolaget LM Ericsson v. Lava Int'l. Ltd., CS(OS) No. 764/2015, Judgment, High Court of Delhi [Del. H.C.] 28 (June 10, 2016), https://spicyip.com/wpcontent/uploads/2016/07/Telefonktiebolaget-Lm-...-vs-Lava-International-Ltd-on-10-June-2016-2.pdf; Unwired Planet Int'l. Ltd. v. Huawei Technologies Co. Ltd [2017] EWHC 711 (Pat) - 92, 95-96 https:// www.judiciary.gov.uk/wp-content/uploads/2017/04/unwired-planet-v-huawei-20170405.pdf, pending appeal, [2017] EWHC 1304 (Pat) 9 70, https://united-kingdom.taylorwessing.com/documents/get/1100/ unwired-planet-v-huawei-judgment-2017-ewhc.pdf/show_on_screen.

6773 F.3d 1201 (Fed. Cir. 2014).

7 Compare Microsoft v. Motorola, 2013 WL 2111217 at*12 (W.D. Wash. Apr. 25, 2013); In re Innovatio IP Ventures, LLC Patent Litig., 2013 WL 5593609 at *8-10 (N.D. Ill. Oct. 3, 2013) with Ericsson v. D-Link, 2013 WL 4046225 at*18 (E.D. Tex. Aug. 6, 2013).

8 See, e.g., Microsoft v. Motorola, 2013 WL 2111217 at *73; In re Innovatio IP Ventures, LLC Patent Litig., 2013 WL 5593609 at $* 9-10$ (using the equal-patent approach as a check on other calculations).
} 
that an invention is valuable-without being anchored to a quantitative market valuation-are insufficiently reliable." 9

The Federal Circuit Ericsson ruling also covered holdup. Consistent with the above views on royalty stacking, the Federal Circuit held that, to be considered as part of a RAND damages analysis, concerns about holdup must be proven using case specific facts rather than theoretical assumptions, stating that "[c]ertainly something more than a general argument that these phenomena are possibilities is necessary." ${ }^{10}$ Instead, the court instructed that to establish holdup, implementers must provide evidence that the SEP holder "used its SEPs to demand higher royalties from standard-compliant companies."11

Similarly, in a case before the International Trade Commission (ITC), In the Matter of Certain Wireless Devices with $3 G$ and/or $4 G$ Capabilities and Components Thereof, Administrative Law Judge (ALJ) Essex stated that he would require proof of actual holdup when considering whether to recommend that the Commission grant an exclusion order on a FRAND-assured SEP. ${ }^{12}$ ALJ Essex further noted that patent hold-out (which refers to the situation when an implementer delays good faith negotiations of a FRAND license) may allow implementers to "exert a pressure on the negotiations with the [intellectual property right] IPR holder to try to make the agreement in the lower range of FRAND, or perhaps even lower than a reasonable FRAND rate." ${ }^{13}$ He also noted that, under the European Telecommunications Standard Institute's Rules of Procedure, "[t]he requirement to negotiate a license rests not just on the IPR owner, but on those companies that would use technology prior to engaging in the [potentially] infringing activities." 14

\footnotetext{
${ }^{9}$ Commw. Sci. and Indus. Research Organisation v. Cisco Sys., Inc., 809 F.3d 1295, 1302 (Fed. Cir. 2015), cert. denied, 136 S. Ct. 2530 (2016).

10773 F.3d at 1234.

${ }^{11} I d$.

${ }^{12}$ In the Matter of Certain Wireless Devices with $3 G$ and/or $4 G$ Capabilities and Components Thereof, ITC Inv. No. 337-TA-868 at 123-124 (June 13, 2014), http://www.essentialpatentblog.com/wp-content/ uploads/sites/64/2014/07/2014.06.26-Initial-Determination-on-Violation-PUBLIC-337-TA-

868smMRC.pdf [hereinafter ALJ Essex Opinion].

${ }^{13} I d$. at 114 .

${ }^{14}$ Id. at 114-115. On August 3, 2013, the United States Trade Representative disapproved a decision by the ITC to grant an exclusion order against Apple, instructing that:
}

in future cases involving SEPs that are subject to voluntary FRAND commitments, the Commission should be certain to (1) examine thoroughly and carefully on its own initiative the public interest issues presented ... and (2) seek proactively to have the parties develop a comprehensive factual record related to these issues . . . including the presence or absence of patent holdup or reverse holdup."

Ltr. Ambassador Michael B. G. Froman, Disapproval of U.S. International Trade Commission's Determination in the Matter of Certain Electromnic Devices, Including Wireless Communication Devices, Portable Music and Data Processing Devices, and Tablet Computers, Investigation No. 337-TA794, at 3 (Aug. 3, 2013), https://ustr.gov/sites/default/files/08032013\%20Letter_1.PDF. The letter relied heavily on the January 8, 2013 policy statement issued by the Department of Justice and the Patent and Trademark Office, which recommends that the ITC consider certain factors, such as holdup and holdout, when determining whether an exclusion order is in the public interest. Policy Statement at https:// www.justice.gov/sites/default/files/atr/legacy/2014/09/18/290994.pdf. 
In a case involving purported proof of an actual patent holdup attempt, Judge Koh, in GPNE Corp. v. Apple, Inc., excluded a patent holder's damages model that sought to factor in a higher royalty rate based on the value the patent obtained by allegedly covering a cellular standard without the patent being subject to a FRAND obligation. ${ }^{15}$ The court reasoned that, among other things, GPNE's expert failed to properly apportion value to the specific patent's technological contribution, and instead sought to "cloak" his "arbitrary" royalty rate on "broad statements about the general value of cellular connectivity." "While the Federal Circuit in Ericsson subsequently held that "the patentee's royalty must be premised on the value of the patented feature, not any value added by the standard's adoption of the patented technology," 17 it is questionable whether a patented technology has a standalone value, separate and distinct from its use. As a result, adoption of a standard will reflect the joint value contributed by all active participants and as such should be shared among them all. ${ }^{18}$

Some courts (across jurisdictions) have concluded that, under certain circumstances, seeking or enforcing injunctive relief on a FRAND-assured SEP can be a form of holdup. ${ }^{19}$ The logic behind this stance is that an injunction is such a harsh remedy-removing the implementer's products from a given market altogetherthat the mere threat of an injunction would be enough to pressure a licensee into accepting supra-FRAND terms and conditions. ${ }^{20}$ As discussed in Sect. 2.2, below,

${ }_{15}$ GPNE Corp. v. Apple, Inc., 2014 WL 1494247 *5-6 (N.D.Cal. Apr. 16, 2014).

${ }^{16} I d$. at 6 .

17 Ericsson, 773 F.3d at 1232.

${ }^{18}$ In Unwired Planet, the court accepted the opinion offered by one economist that "he did not regard FRAND as a scheme which meant the patentee could not appropriate some of the value that is associated with the inclusion of his technology into the standard and the value of the products that are using those standards." Given that neither side disputed this, the court accepted this evidence, stating that the "economists' opinions show that it is not necessary to deprive the patentee of its fair share of those two sources of value in order to eliminate hold up and fulfil the purpose of FRAND." [2017] EWHC 711 (Pat) - 97, https://www.judiciary.gov.uk/wp-content/uploads/2017/04/unwiredplanet-v-huawei-20170405.pdf.

19 Realtek Semiconductor Corp. v. LSI Corp., 946 F. Supp. 2d 998, 1002 (N.D. Cal. 2013); Best IT World (India) Private Ltd. V. Telefonaktiebolaget LM Ericsson, CCI Case No. 4/2015 14 (May 12, 2015), http://www.cci.gov.in/sites/default/files/042015_0.pdf. The U.S. Federal Trade Commission (FTC) has also entered into two consent orders that essentially prohibit a FRAND-assured SEP holder from seeking or enforcing of injunctive relief under the FTC Act's standalone Section 5 "unfair methods of competition" provision. See Decision and Order, In the Matter of Robert Bosch GmbH, Docket No. C-4377 (Apr. 23, 2013), https://www.ftc.gov/sites/default/files/documents/cases/2013/04/130424robertboschdo.pdf; Decision and Order, In the Matter of Motorola Mobility LLC, and Google Inc., Docket No. C-4410, at 7-8 (July 23, 2013), http://www.ftc.gov/sites/default/files/documents/cases/2013/07/130724googlemotorolado.pdf. It is important to note that these were negotiated consents based on standalone Section 5 authority, not on traditional U.S. antitrust law, and that no U.S. court has held that seeking or enforcing injunctive relief on a FRAND-assured SEP constitutes an antitrust violation. See, e.g., Koren W. Wong-Ervin \& Joshua D. Wright, Intellectual Property and Standard Setting, 17 Federalist Society REVIEW 52 (2016), https://papers.ssrn.com/sol3/papers.cfm?abstract_id=2878955.

${ }^{20}$ This is the theoretical argument put forth in Carl Shapiro and Mark Lemley, Injunctions, Hold-Up, and Patent Royalties, 12 Am. Law. Econ. Rev. 280 (2010). In addition, some, such as the FTC in Motorola Mobility/Google, have contended that seeking or enforcing injunctive relief constitutes a breach of the FRAND assurance. Others, such as then Commissioner and now Acting Chairman of the FTC, Maureen Ohlhausen, reject the view that SEP holders impliedly waive their rights to injunctive relief by making a 
the in terrorem (or fear from threat) effect of filing for an injunction depends on the likelihood of that injunction being granted.

In Europe, the question of whether it is anticompetitive to seek an injunction on a FRAND assured patent was addressed in the 2015 European Court of Justice (ECJ) Huawei v. ZTE decision. This case involved a dispute in Germany, where injunctions are an automatic consequence of an infringement; German courts have no discretion in deciding on an injunction. ${ }^{21}$ The German norm was, however, at odds with the standard espoused by the European Commission (EC), motivating the German court to seek clarification from the ECJ. ${ }^{22}$ The ECJ concluded that, while a FRAND-assured SEP holder has the right to bring an action for a prohibitory injunction, its refusal to grant a license "may, in principle, constitute an abuse within the meaning of Article 102 TFEU." 23 The ECJ went on to define the actions that both SEP holders and licensees need to follow in order to benefit from a safe harbor from competition law liability. In particular, a SEP holder needs to do the following: (1) prior to initiating an infringement action, alert the alleged infringer of the claimed infringement and specify the way in which the patent has been infringed; and (2) after the alleged infringer has expressed its willingness to conclude a license agreement on FRAND terms, present to the alleged infringer a specific, written offer for a license, specifying the royalty and calculation methodology. ${ }^{24}$ On the other side of the bargaining table, the ECJ held that the

\section{Footnote 20 continued}

FRAND assurance, requiring instead that there be evidence of a "clear promise" by the SEP holder not to seek an injunction on the specific SEPs at issue. Dissenting Statement in In the Matter of Motorola Mobility LLC, and Google, Inc. at 5 (Jan. 3, 2013), https://www.ftc.gov/sites/default/files/documents/ public_statements/statement-commissioner-maureen-ohlhausen/130103googlemotorolaohlhausen stmt.pdf.

21 The Case Law of the German Courts of Lower Instance for Patent Law and Utility Model Law Since the Year 2013, White \& Case, https://www.whitecase.com/publications/article/case-law-german-courtslower-instance-patent-law-and-utility-model-law-year.

22 In April 2014, the EC, in two separate matters, one involving Samsung Electronics Co., Ltd. and the other involving Motorola Mobility Inc., established a framework for determining whether and under what circumstances patent owners seeking to enforce SEPs in the European Economic Area may violate European Union antitrust laws. The decisions create a "safe harbor" approach from injunctive relief, under which implementers can demonstrate that they are a "willing licensee" by agreeing that a court or a mutually agreed arbitrator shall adjudicate the FRAND terms in the event that negotiations fail. The decisions do not preclude injunctive relief for FRAND-assured SEPs per se, nor do they make findings on the definition of a "willing licensee" outside the safe harbor. For a summary of these decisions, see Koren W. Wong-Ervin, The European Commission's Safe Harbor Approach to the Seeking or Enforcing of Injunctive Relief on FRAND-Encumbered SEPs, 12(1) MonOPOLY MATTERS (ABA Section of Antitrust Law) (Fall 2014), https://sls.gmu.edu/gai/wp-content/uploads/sites/27/2016/07/KWE-ECs-Safe-Harbor.pdf; see also EC MEMO/14/322, Antitrust decisions on standard essential patents (SEPs)—Motorola Mobility and Samsung Electronics-Frequently asked questions (Apr. 29, 2014), http://europa.eu/ rapid/press-release_MEMO-14-322_en.htm. One problem with the "willing licensee" concept is that it is a factual determination that may be far from clear in many cases, and thus "the outcome of an antitrust case will necessarily be uncertain," which is likely to result in overdeterrence. Ginsburg et al., supra note 4 , at 7 .

23 Case C-170/13, Huawei Technologies Co. v. ZTE Corp. ๆ 52-53 (July 16, 2015), http:// curia.europa.eu/juris/document/document.jsf?text $=\&$ docid $=165911 \&$ pageIndex $=0 \&$ doclang $=$ EN\&mode $=1$ st \&dir=\&occ $=$ first $\&$ part $=1 \&$ cid=603775 [hereinafter Huawei $v$. ZTE].

24 Id. 71. 
alleged infringer must "diligently respond" to the SEP holder's offer, "in accordance with recognized commercial practices in the field and in good faith," by promptly providing a specific written counter-offer that corresponds to FRAND terms, and by providing appropriate security (e.g., a bond or funds in escrow) from the time at which the counter-offer is rejected. ${ }^{25}$ For alleged infringers that fail to take these steps, the SEP holder is free to seek an injunction. The decision also recognizes concerns about reverse-holdup, stating that the Court will not tolerate infringers" "delaying tactics." 26

\subsection{Economic discussion}

The Federal Circuit's decision in Ericsson is an important holding that recognizes the economic theory behind holdup and royalty stacking, as discussed above. Holdup of any form requires lock-in, i.e., standard-implementing companies with asset-specific investments locked in to the technologies defining the standard or SEP holders locked in to licensing in the context of a standard because of standardspecific research and development (R\&D) leading to standard-specific patented technologies. $^{27}$

When discussing lock-in, holdup arguments refer regularly to notions of ex ante and ex post, typically using the codification of a standard as the demarcation point between before and after. Competition among different technology solutions that may occur ex ante is contrasted to lock-in and switching costs that may be present ex post, after one of the competing options has been chosen. Indeed, these notions are key elements in assessing whether or not particular terms are FRAND. It is important to understand two points in this context. First, what constitutes ex ante and ex post can differ with perspective: the development period for a standard generally is ex ante for an implementer, but it is ex post for an innovator, who has already sunk its $R \& D$ investments to obtain technologies to contribute to the standard's development. Second, there is no single dividing line between ex ante and ex post: standards evolve over time, with numerous versions and generations published, meaning that one could identify a long list of pre and post points just using standard codification dates. Both of these points together imply that any ex ante/ex post divide, on its own and without more evidence, cannot define holdup.

\footnotetext{
25 Id. $96-67$. In Unwired Planet, the court referred to obligations on both FRAND-assured SEP holders and implementers, reasoning that "the logic of the FRAND undertaking means that an implementer must negotiate fairly if it wishes to take advantage of the constraint which the patentee's FRAND undertaking places on the patentee's rights. Just as an implementer is entitled to demand FRAND terms in a licence from a patentee subject to the ETSI FRAND undertaking, so a patentee is entitled to demand FRAND terms in the same licence. In other words, an implementer who does not negotiate fairly is not a willing licensee and may ultimately be subject to an injunction." [2017] EWHC 711 (Pat) \ 160, https://www.judiciary.gov.uk/wp-content/uploads/2017/04/unwired-planet-v-huawei20170405.pdf.

${ }^{26}$ Huawei v. ZTE, supra note 24, at 55.

27 For a discussion of the theoretical roots of the holdup theory, see Scott Kieff \& Anne Layne-Farrar, Incentive Effects From Different Approaches to Holdup Mitigation Surrounding Patent Remedies and Standard-Setting Organizations, 9(4) J. Competition L. \& Econ. 1091-1123 (2013).
} 
Lock-in is a necessary condition for holdup, but it is not sufficient. For holdup in any guise to actually occur, there also must be an exploitative action taken by the relevant party once lock-in has occurred. As a result, the mere fact that a license agreement was signed after a patent was included in a standard is not enough to establish that the patent holder is practicing holdup-there must also be evidence that the SEP holder took advantage of the licensee's lock-in, for example by charging more than FRAND royalties that it could not otherwise have charged but for the lock-in. More specifically, in order to find actual holdup, two elements must be present: opportunity and action. ${ }^{28}$

Consider first opportunity. Simply having a patent that has been declared as potentially essential to an SDO does not automatically endow that patent holder with a credible threat of holdup - either during negotiations before any lawsuit is filed or in the midst of a lawsuit in relation to settlement proposals or calculated FRAND rates submitted to the trier of fact. Implementers can and regularly do challenge the essentiality of patents declared at SDOs, so a declared essential patent may be found to be not essential during the course of a trial. Even if the patent is indeed found to be essential, or if essentiality is never tested in court, patents are not created equal. This means that for SEPs with FRAND commitments, the value of the patented technology drives the rate determination, not the essentiality. Seeking fees beyond the value contributed by the patented technology is a risky strategy for a SEP holder-as GPNE found in its case against Apple. ${ }^{29}$

Consider next the action prong of holdup. Opportunities must be exploited for any harm to competition to result. Thus, the fact that a license agreement was signed after the patent(s) were included in a standard is not enough to establish that the patent holder is practicing holdup, without additional evidence that the patent holder used its ex post leverage to extort royalty rates in excess of the patented technology's value. A host of practical and commercial reasons lead most SEP licensing negotiations to occur after the relevant standard has been codified, including continually evolving standards and the desire to avoid the costs of unnecessary licensing negotiations for standard elements that do not survive. As a result, while ex ante license agreements are not unheard of, they are relatively rare. Hence, most candidate agreements for comparable licenses will be signed ex post.

Despite coming after a particular standard is published, the vast majority of SEP licenses are concluded in arm's length, bilateral negotiations with no allegations of holdup or opportunistic behavior. This follows because market mechanisms impose a number of constraints that militate against acting on the opportunity for holdup. For example, because standards evolve over time (e.g., mobile standards are commercializing the 4th generation now, with $5 \mathrm{G}$ on the drawing boards), repeated interactions among the participants provide strong behavior incentives for good faith bargaining as bad acts can be punished in the next round of interactions. The risk of getting sued for breach of FRAND is another motivator. Reputational and business costs are yet another factor that can deter players from engaging in holdup. Existing relationships have an impact as well, as the U.S. FTC has acknowledged:

\footnotetext{
${ }^{28} I d$.

${ }^{29}$ GPNE Corp. v. Apple, Inc., 2014 WL 1494247 (N.D.Cal. Apr. 16, 2014).
} 
"patent holders that have broad cross-licensing agreements with the SEP-owner may be protected from hold-up." 30 In addition, patent holders often enjoy a firstmover advantage if their technology is adopted as the standard. "As a result, patent holders who manufacture products using the standardized technology 'may find it more profitable to offer attractive licensing terms in order to promote the adoption of the product using the standard, increasing demand for its product rather than extracting high royalties.",31

In order to rule out post-standard-publication licenses as FRAND benchmarksat least on the basis of potential holdup - an expert must establish that the terms and conditions in the agreement generate payments that exceed the value conveyed by the patented technology to the licensor that signed the agreement. In other words, the evidence should establish that the SEP holder actually took advantage of the opportunity for holdup.

As for the role that injunctions might play in a SEP holder's ability to practice holdup, there is a critical difference between seeking an injunction and obtaining one. The threat of seeking injunctive relief, on its own, cannot lead to holdup unless that threat is both credible and actionable. Indeed, the in terrorem effect of filing for an injunction depends on the likelihood of it being granted. ${ }^{32}$ In the United States, the credibility of an injunction threat fell precipitously after the Supreme Court's decision in eBay $v$. MercExchange LLC, which ended the prior near-automatic granting of injunctions and instead required courts to apply a traditional four-part equitable test for granting injunctive relief. ${ }^{33}$ Empirical evidence shows a significant decline in the number of injunctions sought as well as in the actual rate of injunctions granted in the United States following that ruling. ${ }^{34}$

With respect to injunctions for FRAND-assured SEPs, while the U.S. Court of Appeals for the Federal Circuit rejected a per se rule that injunctions are unavailable for SEPs, it also noted that "[a] patentee subject to FRAND commitments may have difficulty establishing irreparable harm." 35 The court went on, however, to say that,

\footnotetext{
${ }^{30}$ Prepared Statement of The Federal Trade Commission Before the U.S. Senate Committee on the Judiciary Concerning "Standard Essential Patent Disputes and Antitrust Law" at 6 (July 30, 2013), http:// www.ftc.gov/sites/default/files/documents/public_statements/prepared-statement-federal-trade-commission-concerning-standard-essential-patent-disputes-and/130730standardessentialpatents.pdf.

31 Id. (internal citations omitted).

32 Ginsburg, supra note 3, at 94.

33 Kirti Gupta \& Jay P. Kesan, Studying the Impact of eBay on Injunctive Relief in Patent Cases (2016), https://ssrn.com/abstract=2816701 [hereinafter Gupta \& Kesan]. In $e$-Bay, the Supreme Court held that the traditional four-factor test applied by courts of equity when considering whether to award permanent injunctive relief to a prevailing plaintiff applies to disputes arising under the Patent Act. That test requires a plaintiff to demonstrate: (1) that it has suffered an irreparable injury; (2) that remedies available at law are inadequate to compensate for that injury; (3) that considering the balance of hardships between the plaintiff and defendant, a remedy in equity is warranted; and (4) that the public interest would not be disserved by a permanent injunction. eBay Inc. v. MercExchange, L.L.C., 547 U.S. 388, 388 (2006).

34 Gupta \& Kesan, supra note 34.

35 Apple Inc. v. Motorola, Inc., 757 F.3d 1286, 1332 (Fed. Cir. 2014) ("The framework laid out by the Supreme Court in $e$ Bay, as interpreted by subsequent decisions of this court, provides ample strength and flexibility for addressing the unique aspects of RAND committed patents and industry standards in general").
} 
"[o]n the other hand, an injunction may be justified where an infringer unilaterally refuses a FRAND royalty or unreasonably delays negotiations to the same effect." The ability to seek injunctive relief against a licensee that is engaged in holdup or holdout is important to help prevent licensee holdout. In other words, the U.S. Federal Circuit recognized the need for balance between the parties, analogous to the ruling by the ECJ in Huawei.

Note that seeking an injunction against a licensee who is delaying or not negotiating in good faith need not actually result in an injunction. The fact that a court finds a licensee is holding out and/or not engaging in good faith licensing discussions can be enough to spur a license agreement in lieu of a permanent injunction. In this regard, the ECJ Huawei ruling may be seen as addressing the less formal rules for deciding an injunction in Europe, compared to the $e B a y$ guidance in the United States.

Additional decisions recognizing the importance of balance in protecting against both holdup by SEP holders and holdout by implementers include the recent decisions by the Delhi High Court. Those cases granted Ericsson's requests for interim injunctions on FRAND-assured SEPs against several unwilling licensees. ${ }^{36}$ Similarly, in March 2017, the Beijing Intellectual Property Court granted an injunction for a FRAND-assured SEP holder in IWNCOMM v. Sony, awarding treble damages for infringement. ${ }^{37}$ The Court's decision was based on its finding that the implementer willfully delayed the negotiations and was at fault during the six years of negotiations, stating that the implementer's repeated insistence on the patent claim chart was unreasonable where the SEP holder had already provided sufficient documents for the implementer to determine whether their products infringed the relevant SEPs. ${ }^{38}$ Also, post Huawei, the Dusseldorf Higher Regional

\footnotetext{
36 Telefonaktiebolaget LM Ericsson v. Mercury Elecs., CS(OS) No. 442/2013, Order, High Court of Delhi [Del. H.C.] at 3 (Mar. 6, 2013), http://delhihighcourt.nic.in/dhcqrydisp_o.asp?pn=46519\&yr=2013; Telefonaktiebolaget LM Ericsson v Intex Techs. (India) Ltd., CS(OS) No. 1045/2014, Judgement, High Court of Delhi [Del. H.C.] \ 159-162 (Mar. 13, 2015), http://lobis.nic.in/ddir/dhc/MAN/judgement/1603-2015/MAN13032015S10452014.pdf; Telefonaktiebolaget LM Ericsson v. Xiaomi Tech., CS(OS) 3775/2014, Judgment, High Court of Delhi [Del. H.C.] 26 (Apr. 22, 2016), http://lobis.nic.in/ddir/dhc/ VKR/judgement/23-04-2016/VKR22042016S37752014.pdf; Telefonaktiebolaget LM Ericsson v. Lava Int'l. Ltd., CS(OS) No. 764/2015, Judgment, High Court of Delhi [Del. H.C.] 1 114-115 (June 10, 2016), https://spicyip.com/wp-content/uploads/2016/07/Telefonktiebolaget-Lm-...-vs-Lava-International-Ltd-on-10-June-2016-2.pdf.

37 Su Sun, IWNCOMM v. Sony: Recent Development in FRAND Litigation in China, EconomIST INK (Summer 2017), https://ei.com/economists-ink/summer-2017/iwncomm-v-sony-recent-developmentfrand-litigation-china/.

38 Id. With respect to competition agencies, in February 2014, the Korea Fair Trade Commission (KFTC) issued a decision concluding that Samsung's injunction claims against Apple on SEPs related to 3G mobile communication technology did not constitute an abuse of dominance or unfair trade practice where Apple failed to engage in good faith negotiations and instead engaged in reverse holdup. Specifically, the KFTC found that Apple was not a willing licensee because it (1) filed patent infringement litigation against Samsung while proceeding with negotiations, (2) proposed license terms that devalued Samsung's patent value, and (3) engaged in reverse holdup as evidenced by the fact that it did not have the intent to pay any royalties until the litigation was concluded. Conversely, the KFTC found that Samsung did negotiate in good faith because (1) before and after filing the injunction claims, Samsung proposed various license terms to Apple and proceeded with substantial negotiations, and (2) the royalty rates proposed by Samsung were not excessive. KFTC Press Release (Feb. 26, 2014), http://
} 
Court affirmed the lower court's decision to grant an injunction against Vodafone in St. Lawrence v. Vodafone on the grounds that Vodafone failed to make a counteroffer or declare its willingness to negotiate in a timely manner. ${ }^{39}$ Similarly, in the United Kingdom, the court in Unwired Planet granted an injunction against Huawei on Unwired Planet's FRAND-assured SEPs concluding that Huawei's refusal to offer an unqualified undertaking (i.e., its refusal to accept a worldwide license) before trial and judgement warranted the injunction, albeit one which will be stayed on terms pending appeal. ${ }^{40}$

With respect to royalty stacking, the key point to bear in mind is that patents are not created equal. FRAND rates should reflect the value of the SEPs at issue, so it makes no economic sense to estimate an aggregate rate for a standard by assuming that all SEP holders would charge the same rate as the one being challenged in the current lawsuit. A numeric example illustrates how this estimation approach can go horribly wrong. Suppose that a standard is defined by 5 SEPs (1-5), with one patent each held by 5 patent holders (A-E). The value the set of 5 patents contribute to the standard (as embodied in the downstream product) is known to be 10 per product unit. Suppose that patent 1 accounts for $50 \%$ of the aggregate value of 10 , patent 2 accounts for $20 \%$ of the value, while patents 3-5 each account for $10 \%$. Each patent is a perfect complement (must be used together to achieve any product value); each is thus essential, but the values are not equal. FRAND would dictate that patent 1 can command a per-unit royalty of 5, patent 2 can command 2, and patents 3-5 can command 1 each. Suppose patent holder A is the first to seek a license and asks for 5 per unit, commensurate with its FRAND value. But under the common estimation approach, the downstream manufacturer will accuse that patent holder of holdup because the aggregate royalty estimated by multiplying the offered rate of 5 by the 5 patent holders implies a total rate of 25 , two and a half times larger than the known value contributed by all 5 patents together. A judge accepting this argument would wrongly conclude that patent holder A was attempting holdup and creating or contributing to a royalty stack. Suppose instead that SEP holder E is the first to seek a license and it sets its offer at 2, twice as much as the value of its patented technology. In this case, a judge multiplying the rate by the 5 essential patents would conclude, again wrongly, that this rate was FRAND as the aggregate rate of 10 exactly equals the known value of the 5 patents-even though SEP holder E was asking for twice the value that its patent contributes to the standard. In short, assuming equal-patent value and taking a simple multiplication approach to estimate an aggregate royalty stack will only be right by happenstance. Most often it will yield the wrong answer, sometimes absolving rates that actually exceed

\footnotetext{
Footnote 38 continued

www.ftc.go.kr/news/ftc/reportView.jsp?report_data_no=5542\&tribu_type_cd=\&report_data_div_cd= $\&$ currpage $=2 \&$ searchKey $=\&$ searchVal $=\&$ stdate $=\&$ enddate (in Korean) .

39 Taylor Wessing, Düsseldorf Regional Court further sharpens its notion of the FRAND-obligations of SEP-Proprietor and SEP-user, LEXOLOGY (Apr. 12, 2016), http://www.lexology.com/library/detail.aspx?g=21ba15a4-f3e6-4042-9834-4c1070fc30ec.

40 Unwired Planet Int'l. Ltd. v. Huawei Tech. Co. Ltd [2017] EWHC 1304 (Pat) 9 3, https://unitedkingdom.taylorwessing.com/documents/get/1100/unwired-planet-v-huawei-judgment-2017-ewhc.pdf/ show_on_screen.
} 
FRAND and other times condemning genuine FRAND rates. Thus, this approach should not be used to assess royalty stacking-even as a check on other calculations (as suggested by Judge Holderman in Innovatio)-because it risks both false positives and false negatives.

Based on the underlying economics, we agree with the Federal Circuit that royalty stacking allegations should be backed by case-specific evidence. Especially for products embodying well-established standards, like $\mathrm{Wi}-\mathrm{Fi}$ and mobile, manufacturers should be able to present data on the aggregate rates that they actually pay, supplemented (when appropriate) by credible evidence on additional patent holders that are realistically expected to seek royalties.

More fundamentally, as discussed in the next section below, when a FRAND assessment is focused on the value that the SEP portfolio at issue has contributed to the standard and products embodying the standard, the resulting rates and terms will necessarily avoid both patent holdup and royalty stacking.

\section{Competing methodologies for FRAND determinations}

This section discusses methodologies proposed to and relied on by courts for linking FRAND royalties and damages to the SEP portfolio value contributed to the standard and to products embodying that standard. Our discussion is organized by the methodologies adopted by the courts to date, which include the "hypothetical negotiation" approach combined with the other 14 Georgia-Pacific factors (15 factors total), ${ }^{41}$ the comparable licenses method, and reliance on the "incremental value" rule.

\subsection{Court rulings}

\subsubsection{Hypothetical negotiations \& the Georgia-Pacific factors}

In the United States, the Georgia-Pacific case provides the most common framework for guiding damages in patent infringement matters. The judge in that case called for evaluating a "hypothetical negotiation" between the two parties assuming they were both willing to conclude a license; he also listed a set of 14 other "factors" that should be accounted for in that but-for world assessment. Judge Holderman (in Innovatio) explained the approach as follows: "The purpose of conducting such a hypothetical negotiation is 'to ascertain the royalty upon which the parties would have agreed had they successfully negotiated an agreement just before infringement began.' Accordingly, the court must try, 'as best as possible, to recreate the ex ante licensing negotiation scenario and to describe the resulting agreement.", 42

\footnotetext{
${ }^{41}$ Georgia-P. Corp. v. U.S. Plywood Corp., 318 F. Supp. 1116, 1120 (S.D.N.Y. 1970), modified sub nom. Georgia-P. Corp. v. U.S. Plywood-Champion Papers, Inc., 446 F.2d 295 (2d Cir. 1971).

42 In re Innovatio IP Ventures, LLC Patent Litig., 2013 WL 5593609 at *5 (N.D. Ill. Oct. 3, 2013) (internal citation omitted).
} 
As U.S. courts have relied on the Georgia-Pacific framework for over 40 years, it provided a natural candidate framework for SEP license assessments. ${ }^{43}$ Several lower courts applied a modified version of the 15 factors to recreate a hypothetical negotiation between the parties as the best starting point for FRAND assessments, where the modifications were meant to address the unique circumstances of SEP licensing.

On April 19, 2013, U.S. District Court Judge Robart became the first U.S. judge to take this approach. In Microsoft v. Motorola, Judge Robart determined a FRAND royalty rate and range for standard-essential patents in a contract dispute between Microsoft and Motorola over SEP portfolios relevant to two industry standards, WiFi and H.264 (for video coding). ${ }^{44}$ Judge Robart modified the traditional GeorgiaPacific factors so that they might better reflect the obligations embodied in a FRAND commitment:

Factor 1 The royalties received by the patentee for the licensing of the patentin-suit in other circumstances comparable to FRAND-licensing circumstances.

Factor 2 The rates paid by the licensee for the use of other patents comparable to the patent-in-suit (unchanged).

Factor 3 The nature and scope of the license (unchanged).

Factors 4-5 Do not apply in the FRAND context at all; both were dropped.

(Factor 4 relates to the licensor's policy and marketing program;

Factor 5 relates to the commercial relationship between the licensor and licensee).

Factor 6 The effect of the patented invention in promoting sales of other products of the licensee and the licensor, taking into account only the value of the patented technology and not the value associated with incorporating the patented technology into the standard.

Factor 7 In the FRAND context, the analysis of this factor (related to the duration of the patent and the term of the license) is greatly simplified because the term of the license would be co-extensive with the duration of the patent.

Factor 8 The established profitability of the product made under the patent, its commercial success, and its current popularity, taking into account only the value of the patented technology and not the value associated with incorporating the patented technology into the standard.

Factor 9 The utility and advantages of the patent property over alternatives that could have been written into the standard instead of the patented technology in the period before the standard was adopted.

\footnotetext{
43 See, e.g., Anne Layne-Farrar et. al., Pricing Patents for Licensing in Standard Setting Organisations: Making Sense of FRAND Commitments, ANTITRUST L.J., Winter 2007.

442013 WL 2111217 at *101 (W.D. Wash. Apr. 19, 2013), aff'd Microsoft Corp. v. Motorola, Inc., 696 F.3d 872 (9th Cir. 2012). The case involved a claim that Motorola breached its RAND contract obligation and the court determined that, without a clear understanding of what RAND means, it would be difficult or impossible to determine whether Motorola breached its obligation to license its patents on RAND terms. Importantly, the case has limited precedential effect given that the court found that Motorola had waived virtually all issues it raised on appeal.
} 
Factors The contribution of the patent to the technical capabilities of the standard 10-11 and also the contribution of those relevant technical capabilities to the licensee and the licensee's products, taking into account only the value of the patented technology and not the value associated with incorporating the patented technology into the standard.

Factor 12 The portion of the profit or of the selling price that may be customary in the particular business or in comparable businesses to allow for the use of the invention or analogous inventions that are also covered by FRAND-committed patents.

Factor 13 The portion of the realizable profit that should be credited to the invention as distinguished from non-patented elements, the manufacturing process, business risks, significant features or improvements added by the infringer, or the value of the patent's incorporation into the standard.

Factor 14 The opinion testimony of qualified experts (unchanged).

Factor 15 The amount that a licensor and a licensee would have agreed upon (at the time the infringement began) if both were considering the

FRAND commitment and its purposes, and had been reasonably and voluntarily trying to reach an agreement.

Regarding the date of the hypothetical negotiation, Judge Robart held that the exercise must reconstruct the negotiation that would have taken place between the parties prior to the date on which the patented invention was adopted as a part of the industry standard.

Shortly after Judge Robart issued his opinion, Judge Holderman (on October 3, 2013), at the request of the parties, adopted the hypothetical negotiation approach in In re Innovatio IP Ventures, LLC Patent Litig., although with revisions to match the different circumstances of the Innovatio case. ${ }^{45}$ The parties agreed that the appropriate date for the hypothetical negotiation was "around the time of the initial adoption of the 802.11 standard, and therefore approximately the time when the manufacturers began selling 802.11 compliant products." As a consequence, the negotiating parties would have negotiated a single license covering all subsequently obtained 802.11 SEPs. $^{46}$

The jury in Innovatio found that three of Ericsson's 802.11n (Wi-Fi) SEPs were infringed and awarded lump sum damages, which the court then translated into a per-unit RAND rate for ongoing future royalty payments. According to Judge Holderman, "[a]s a practical matter," Judge Robart's analysis proceeded in three steps, "which provide a framework for any court attempting to determine a RAND licensing rate for a given patent portfolio." 47

First, a court should consider the importance of the patent portfolio to the standard, considering both the proportion of all patents essential to the standard that are in the portfolio, and also the technical contribution of the patent portfolio as a whole to the standard.

\footnotetext{
45 Innovatio, 2013 WL 5593609 at 6.

46 Id. at 8.

47 Id.
} 
Second, a court should consider the importance of the patent portfolio as a whole to the alleged infringer's accused products.

Third, a court should examine other licenses for comparable patents to determine a RAND rate to license the patent portfolio, using its conclusions about the importance of the portfolio to the standard and to the alleged infringer's products to determine whether a given license or set of licenses is comparable. ${ }^{48}$

Judge Holderman made two important modifications to Judge Robart's approach. First, Judge Holderman refused to adjust the license rate for SEPs whose essentiality was questionable prior to the court's adjudication. He acknowledged that such adjustment "may seem reasonable" given that "[t]he hypothetical negotiation tries ... to recreate the ex ante licensing negotiation scenario and to describe the resulting agreement." 49 Yet, he explained that, at the time a court is evaluating damages in a patent infringement suit, it has determined whether the patent is valid and infringed, "foreclosing the hypothetical negotiator from benefiting from any uncertainty as to future court rulings." Thus, "it would be inappropriate to adjust the RAND rate based upon pre-litigation uncertainty." 50

Second, Judge Holderman found that his determination that the appropriate royalty base was the Wi-Fi chip "effectively merge[d]" steps one and two of Judge Robart's methodology, explaining that "[b]ecause the purpose of a Wi-Fi chip is, by definition, to provide 802.11 functionality, determining the importance of Innovatio's patents to the 802.11 standard also determines the importance of those patents to the Wi-Fi chip." 51

Since these two initial court rulings, several U.S. juries have also determined RAND royalty rates or damages based on instructions to apply a modified-version of the Georgia-Pacific test. In Realtek $v$ LSI, the jury awarded percentage royalties per Wi-Fi chip for the two SEPs at issue. ${ }^{52}$ In Ericsson v. D-Link, the jury awarded lump sum damages to compensate Ericsson for the defendants' past infringement based on jury instructions that modified the Georgia-Pacific factors to include Ericsson's obligation to license its patents on RAND terms. ${ }^{53}$ That court refused to

\footnotetext{
48 Innovatio, 2013 WL 5593609 at 6.

49 Id. at 7.

${ }^{50} \mathrm{Id}$.

51 Id. at 8 .

52 Jury Instructions, Realtek v. LSI, Case No. 5:12-cv-03451 Instruction Nos. 12-15 (Feb. 23, 2014), http://www.essentialpatentblog.com/wp-content/uploads/sites/234/2014/02/2014.02.23-298-Jury-Instructions.pdf; Jury Verdict Form, Realtek v LSI, Case No. 5:12-cv-03451 (N.D. Cal. Feb. 26, 2014), http:// www.essentialpatentblog.com/wp-content/uploads/sites/234/2014/02/2014.02.27-324-Verdict.pdf. Following the jury award, Judge Whyte entered final judgment in favor of Realtek in the amount of $\$ 3.8$ million in contractual damages consistent with the jury's special verdict. The court also granted Realtek's request for a declaratory judgment that, to be in compliance with its RAND commitment, LSI must offer Realtek licenses consistent with the jury's award. Case No. 5:12-cv-03451 (N.D. Cal. June 16, 2014), http://assets.law360news.com/0548000/548585/Order\%202.pdf.

53 Ericsson Inc. v. D-Link Sys, Inc., 2013 WL 4046225 at*22 (E.D.Tex. Aug. 2013); see also Final Jury Verdict, Ericsson Inc. v. D-Link Sys., Inc., Case No. 6:10-cv-00473 (E.D.Tex June 13, 2013), http:// www.essentialpatentblog.com/wp-content/uploads/sites/234/2013/06/Ericsson-v-D-Link-JuryVerdict.pdf.
} 
determine a RAND rate, however, stating that the "Defendants cannot ask the Court to determine a RAND rate but refuse to be bound by it." 54

After a number of lower court rulings based on modified Georgia-Pacific factors, however, the Federal Circuit in Ericsson held that "[t]here is no Georgia-Pacificlike list of factors that district courts can parrot for every case involving RANDencumbered patents." 55 Instead, the Federal Circuit ruled that if a court chooses to follow the Georgia-Pacific approach, it must instruct the jury only on those factors that are relevant to the record developed at trial, and must also instruct the jury on the actual RAND commitment at issue, based on the relevant SDO language.

Though the Federal Circuit in Ericsson refused to provide a recommended modification of all 15 of the Georgia Pacific Factors for universal use in RAND cases, it did provide some further guidance on this issue. For example, the court noted that "[i]n a case involving RAND-encumbered patents, many of the GeorgiaPacific factors simply are not relevant; many are even contrary to RAND principles." Namely, the licensor's established policy to maintain its patent monopoly (Georgia Pacific Factor 4) and the relationship between the SEP holder and the putative licensee (Georgia Pacific Factor 5) will never be relevant for a SEP holder who has committed to RAND licensing. While a SEP holder can legitimately charge differently situated licensees different rates reflecting the differential value those licensees receive from the patented technologies, the "ND" portion of RAND prevents SEP holders from discriminating on the basis of whether or not it competes directly with the licensee.

\subsubsection{Comparable licenses}

The second approach seen in rulings from China, the United Kingdom, and the United States thus far focuses on just two of the Georgia-Pacific factors, factors 1 and 2 on comparable licenses.

In the first-ever FRAND damages determination, the Shenzhen Intermediate People's Court in Huawei v. InterDigital determined that the royalties Huawei should pay for use of InterDigital's 2G, 3G, and 4G essential Chinese patents should not exceed 0.019 percent of the actual sales price of each Huawei product. ${ }^{56}$ While the Shenzhen court did not explain its calculation methodology, the three judges who ruled on this case wrote an article (translated in part in an article by Fei Deng and Su Sun) that provides more details on their reasoning; namely:

when comparing the terms of the offers that the defendant made to the plaintiff with the terms of the licenses that the defendant signed with Samsung, Apple, and others, regardless of using the standard of one-time lump sum payment or per unit royalty rate, the rates stated in the offers are much higher than those in the licenses to Samsung, Apple, and others. The defendant not only demanded high royalty rates, but also forced the plaintiff to license all of its patents back

\footnotetext{
54 Ericsson, $2013 \mathrm{WL} 4046225$ at 22.

55773 F.3d at 1235.

56 InterDigital Commun., Inc. v. Huawei Inv. \& Holding Co., Ltd., Zongji Renmin Fayuan (2013).
} 
for free, bringing extra benefits to the defendant. These indicate that the defendant's pricing was too high and discriminatory. Investigation shows that both the quality and the quantity of the patents owned by the plaintiff are much higher than those of the patents owned by the defendant. In other words, the market and technological value of the plaintiff's patents is much higher than that of the defendant's. In the mobile communications area, crosslicensing between owners of essential patents is not anti-competitive. But because the defendant does not manufacture any goods and the defendant's business model is licensing only, the defendant is enabled to receive extra benefits, which further exacerbates the high royalty rates in the defendant's offers. These indicate that the defendant has violated its FRAND commitment. $^{57}$

As Deng and Sun conclude, "[o]ne may infer from the statement above that the court used InterDigital's licenses with Samsung, Apple, and others as comparable licenses to determine whether the royalty rates InterDigital offered to Huawei were discriminatory, and possibly also to calculate the appropriate FRAND royalty rate that should be charged to Huawei, which was determined to be no more than 0.019 percent." 58

On October 16, 2013, the Guangdong Province High Court issued a ruling affirming the ruling of the Shenzhen Intermediate People's Court. While we do not have access to an English version of the decision, according to InterDigital's 2015 $10 \mathrm{~K}$ filing, in determining a purported FRAND rate, the Chinese court "evaluat[ed] InterDigital's lump-sum patent license agreement with Apple in hindsight to posit a running royalty rate." 59 In its April 2014 petition for retrial to China's Supreme People's Court, InterDigital argued, among other things, that

(1) the lower court improperly determined a Chinese FRAND running royalty rate by using as a benchmark the Apple lump sum fixed payment license agreement, and looking in hindsight at the unexpectedly successful sales of Apple iPhones to construct an artificial running royalty rate that neither InterDigital nor Apple could have intended and that would have varied significantly depending on the relative success or failure in hindsight of Apple iPhone sales;

(2) the Apple license agreement was also an inappropriate benchmark because its scope of product coverage was significantly limited as compared to the license that the court was considering for Huawei, particularly when there are other more comparable license agreements; and

(3) if the appropriate benchmarks had been used, and the court had considered the range of royalties offered by other similarly situated SEP holders in the

\footnotetext{
57 Fei Deng \& Su Sun, Determining the FRAND Rate: U.S. Perspective on Huawei v. InterDigital, Competition Policy InTernational Antitrust Chron. (2014), https://www.competitionpolicyinternational.com/assets/Uploads/DengSunFEB-14.pdf.

58 Id at 7.

59 InterDigital Inc., 1, 24 (Dec. 31, 2015) Form 10-K, https://www.sec.gov/Archives/edgar/data/ 1405495/000140549516000047/idcc-20151231x10k.htm.
} 
wireless telecommunications industry, the court would have determined a RAND royalty that was substantially higher than $0.019 \%$, and would have found, consistent with findings of the ALJ's initial determination in the USITC 337-TA-800 proceeding, that there was no proof that InterDigital's offers to Huawei violated its FRAND commitments. ${ }^{60}$

According to InterDigital's counsel, the company was also precluded from introducing comparable licensing agreements because of non-disclosure agreements, and " $\mathrm{t}]$ he court refused to look at licensing practices by other SEP holders in the industry, including Huawei's own practices." 61 Instead, the court looked at InterDigital's licensing agreements with Apple (from 2007) and Samsung (from 2013), both of which were lump sum royalty fees agreements, and ultimately decided to rely solely on the 2007 Apple agreement on the grounds that the Samsung agreement was reached in settlement of litigation. ${ }^{62}$ According to InterDigital, had the court applied the same methodology (i.e., calculating an "effective rate" using actual sales) to the Samsung licensing agreement, the effective rate would have been 0.19 percent, or ten times the Apple rate. ${ }^{63}$

The U.S. courts have generally considered royalties received by the patentee for the licensing of the patent-in-suit in other circumstances comparable to FRANDlicensing circumstances. In Ericsson, the Federal Circuit explained that, while prior licenses "are almost never perfectly analogous to the [licenses at issue in a later] infringement action," this shortcoming "generally goes to the weight of the evidence, not its admissibility." 64 For example, allegedly comparable licenses may cover more patents than are at issue in the current action, or include cross-licensing terms, or cover foreign intellectual property rights, or be calculated as some percentage of the value of a multi-component product. "Testimony relying on comparable licenses must account for such distinguishing facts when invoking them to value the patented invention." 65

One such "distinguishing factor" can be the royalty base employed in the RAND determination. For example, as the Federal Circuit clarified in Ericsson, juries may hear evidence about comparable licenses based on the end product rather than the SSPPU, reasoning that "[m]aking real world, relevant licenses inadmissible ... would often make it impossible for a patentee to resort to license-based evidence."66 In CSIRO v. Cisco Systems, the Federal Circuit reiterated its holding from Ericsson, stating that "otherwise comparable licenses are not inadmissible solely because they express the royalty rate as a percentage of total revenues, rather than in terms of the

${ }^{61}$ Stuart M. Chemtob, Approaches to FRAND Issues in China and Korea, Law Seminars International at 10-12 (Oct. 30, 2014) (on file with authors).

${ }^{62} \mathrm{Id}$.

${ }^{63}$ Id. Note that Anne Layne-Farrar submitted to the Supreme People's Court a report on behalf of InterDigital in the company's appeal of this matter. Here, however, we have relied only on publicly available documents.

${ }^{64}$ Ericsson, 773 F.3d at 1227.

${ }^{65} \mathrm{Id}$.

${ }^{66} I d$. at 1228 .
} 
smallest salable unit." ${ }^{67}$ In rejecting Cisco's contention that all damages models must begin with the SSPPU approach (which the court described as an "untenable" position that conflicts with its prior approvals of a methodology that values the asserted patent based on comparable licenses), the court explained that such a position would "necessitate exclusion of comparable license valuations that - at least in some cases - may be the most effective method of estimating the asserted patent's value." 68 Accordingly, the court "conclude[d] that the district court did not violate apportionment principles in employing a damages model that took account of the parties' informal negotiations with respect to the end product." 69

In Microsoft, Judge Robart looked beyond the set of potential comparable licenses and added patent pool rates to the list of allowable benchmarks. Although the court agreed "as a general matter that patent pools tend to produce lower rates than those that could be achieved through bilateral negotiation," Judge Robart nevertheless found that rates offered by patent pools (in his case, the MPEG LA H.264 pool and the Via Licensing 802.11 pool) "served as good indicators of a RAND royalty rate" for Motorola's relatively low value SEPs. ${ }^{70}$ The basic foundation for Judge Robart's view is the fact that modern patent pools are largely bundles of SEPs related to particular standards, and as such, Judge Robart reasoned that they offer comparable value for low-value strictly complementary patents.

In contrast, in Innovatio, Judge Holderman found that the Via Licensing 802.11 pool was "not an appropriate comparable license," distinguishing Judge Robart's decision on the grounds that Judge Robart determined that Motorola's 802.11 patents were not important to the 802.11 standard, whereas Innovatio's patent portfolio is of "moderate to moderate-high importance to the 802.11 standard."71 Judge Holderman identified numerous additional problems with using the Via pool rate as a comparable, including the fact that the pool had not been successful (the pool had only five licensors, thirty-five patents, and eleven licensees); did not include high value patents; did not distinguish between patents in the pool on the basis of technical merit, but rather gave the exact same royalty to all patents in the pool; and did not consider the importance of the patents to the implementer's products. Judge Holderman further noted that, because the Via patent pool did not allocate royalties among SEP holders based on relative merit, patent holders with valuable patents would not contribute their technology to the pool, but would instead seek to license those patents bilaterally. "As a result, the pool rates may be considerably depressed." 72

Judge Holderman did not make any general statements on whether non-RAND licenses can ever be useful in determining a RAND rate. He did conclude, however, that because the evidence in the record was "insufficient for the court to determine

\footnotetext{
67 Commw. Sci. and Indus. Research Organisation v. Cisco Sys., Inc., 809 F.3d 1295, 1303 (Fed. Cir. 2015), cert. denied, 136 S. Ct. 2530 (2016).

68 Id. at 1303-1304.

69 Id. at 1304.

70 Microsoft, 2013 WL 2111217 at 80.

71 Innovatio, 2013 WL 5593609 at 36.

${ }^{72} \mathrm{Id}$.
} 
the relative merit of the patented technology in each of those licenses compared with the technology in Innovatio's patents, the court rejects the use of non-RAND licenses and finds that they are "unreliable indicators in this case of the appropriate RAND rate.","73

Judge Holderman also rejected Innovatio's other proposed comparable licenses on various grounds, including that the rates: were "adopted under the duress of litigation"; were determined only as part of a package deal involving a larger patent portfolio; were based on large patent portfolios, such that the rate would not be appropriate for an agreement including a significantly smaller number of patents (note that Judge Holderman's decision was issued before the Federal Circuit explicitly ruled that portfolio licenses were permissible comparables); were based on different standards; or failed to provide any indication of how valuable the patents were compared to other patents in the portfolio. ${ }^{74}$

In SK Hynix Inc. v. Rambus Inc., a case in which the court set a RAND rate as a sanction against Rambus for spoliation, Judge Whyte followed Judge Robart, concluding that "a monetary sanction that takes into account the royalty rates negotiated and paid by SK Hynix's primary competitors is ... [an] appropriate and straightforward way to mitigate the prejudice to SK Hynix caused by Rambus's spoliation." 75 Thus, the court based its RAND rate determination on other Rambus licenses, based on the effective, not stated, rates.

In Golden Bridge Techn. v. Apple Inc., Magistrate Judge Grewal excluded Golden Bridge's expert's RAND royalty calculation based in large part on portfolio licenses Apple signed with Ericsson and Nokia. Magistrate Judge Grewel's rationale was that, "under established Federal Circuit law, an expert may not rely on broad licenses that cover technologies far beyond the patents-in-suit without accounting for the differences in his calculations," which the expert failed to do. ${ }^{76}$ The court pointed to several significant flaws in the expert's report, including improperly and sub silencio allocating the entire value of Apple's portfolio license with Ericsson and Nokia "to a tiny subset of a subset of a subset of a subset of the patents and standards in those portfolios" and failing to allocate any value to the non-license terms of the Ericsson and Nokia agreements. According to the court, the expert's assumption that the "entire dollar value of the Apple-Ericsson and Apple-Nokia agreements stemmed entirely from the actually-essential (not just declared essential) WCMDA patents (not those related to other active standards) relating to terminal devices is an implausible assumption to begin with .... Each of the other errors identified by Apple then compound this basic error." 77

Similarly, in the United Kingdom, the recent ruling in Unwired Planet confirms that use of comparable licenses are permissible. The court there held that a FRAND

\footnotetext{
73 Id.

74 Id. at 31-35.

752013 WL 1915865 at 20 (N.D. Cal. 2013).

76 Order RE: Apple's Second Motion to Exclude Karl Schulze and Motions in Limine, Case No. 5:12-cv04882, at 3 (June 1, 2014), http://www.essentialpatentblog.com/wp-content/uploads/sites/234/2014/06/ 2014.06.01-494-Order-Re-Apple\%E2\%80\%99s-Second-Motion-to-Exclude.pdf.

77 Id.
} 
rate can be determined by using comparable licenses, and that freely negotiated licenses are relevant evidence of what may be FRAND. ${ }^{78}$ Specifically, the court stated that:

To the extent they are available other licences may be deployed as comparables. Just as comparables may be useful in a damages enquiry when considering a reasonable royalty and may be useful in determining the terms of a licence of right or in a Copyright Tribunal, so comparables may be useful in deciding what is FRAND. As always judgments will have to be made about how closely comparable any given licence is to the relevant circumstances in issue. The relevance of comparables is that they are evidence of what real parties in real negotiations have agreed upon. But like any real situation many factors may have been in play which make the licence less relevant. The negotiations may have involved a greater or lesser degree of hold up or hold out and it may be impossible to know that from the evidence available. ${ }^{79}$

To deal with the fact that some otherwise comparable licenses are likely to cover more SEPs, or SEPs plus non-SEPs, the UK court resorted to a form of patent counting. For example, if another SEP holder charges 5\% but has contributed twice as many SEPs to the standard than the SEP holder of interest, then absent any reliable value weighting, this fact would suggest a rate of $2.5 \%$ for the current case. The court recognized that relying on simple patent counts was an imperfect shortcut, but concluded that, "[i]ndeed when one thinks about it some sort of patent counting is the only practical approach at least for a portfolio of any size. Trying to evaluate the importance of individual inventions becomes disproportionate very quickly." 80 The court went on to state, however, that

I suppose in some cases it may be possible to identify a patent as an exceptional sort of keystone invention underpinning the entire technical approach on which a standard is based but that is not this case. There was unchallenged evidence that Unwired Planet's patents made an "average" contribution to the standards. I am satisfied that none of the Unwired Planet patents are in the exceptional keystone category. ${ }^{81}$

\subsubsection{The incremental value rule}

While not explicitly addressed by the Federal Circuit, some implementers as well as the U.S. FTC have recommended determining FRAND value through the "incremental value rule." 82 This method was first put forward in the literature by

\footnotetext{
$\overline{78}$ Unwired Planet Int'l. Ltd. v. Huawei Tech. Co. Ltd [2017] EWHC 711 (Pat) - 806, https:// www.judiciary.gov.uk/wp-content/uploads/2017/04/unwired-planet-v-huawei-20170405.pdf.

${ }^{79}$ Id at 170.

${ }^{80}$ Id. 182.

${ }^{81} I d . \uparrow 184$.

${ }^{82}$ See, e.g., U.S. Federal Trade Commission, The Evolving IP Marketplace: Aligning Patent Notice and Remedies with Competition at 21-22 (Mar. 2011), https://www.ftc.gov/sites/default/files/documents/ reports/evolving-ip-marketplace-aligning-patent-notice-and-remedies-competition-report-federal-trade/
} 
economists extending a price theory for traditional physical products which holds that courts should recognize that the incremental value of the patented technology over the next-best alternative establishes the maximum amount that a willing licensee would pay in a hypothetical negotiation. Given this negotiation maximum, proponents argue that reasonable royalty damages should be no higher than this amount.

In Microsoft v. Motorola, Judge Robart rejected in part an "incremental value" approach on the grounds that it lacks "real-world applicability." 83 He argued that "explicit multilateral ex ante negotiations cannot be conducted under the auspices of many SSOs," and hence the incremental value rule is therefore impractical for courts to implement:

In practice, approaches linking the value of a patent to its incremental contribution to a standard are hard to implement. Calculating incremental value for multipatent standards 'gets very complicated, because when you take one patent out of a standard and put another one in you may make other changes, the performance of the standard is multidimensional, different people value different aspects. ${ }^{84}$

Judge Robart went on to say:

Nevertheless, a reasonable royalty rate for an SEP committed to a RAND obligation must value the patented technology itself, which necessarily requires considering the importance and contribution of the patent to the standard. If alternatives available to the patented technology would have provided the same or similar technical contribution to the standard, the actual value provided by the patented technology is its incremental contribution. Thus, comparison of the patented technology to the alternatives that the SSO could have written into the standard is a consideration in determining a RAND royalty. ${ }^{85}$

Ultimately, Judge Robart concluded that the incremental value approach is "realized, in part" through Factor 9 of Georgia-Pacific, which considers the utility and advantages of the patent property over the old modes or devices, if any, that had been used for working out similar results. ${ }^{86}$

In Innovatio, Judge Holderman rejected the manufacturers' "Bottom Up" approach for calculating a RAND royalty, a method that shares a number of commonalities with the incremental value rule. Specifically, the Bottom Up approach suggests determining the costs of implementing reasonable alternatives to

\footnotetext{
Footnote 82 continued

110307patentreport.pdf. While the Federal Circuit in Ericsson referred to the "incremental value of the invention," it was not referring to the FTC's "incremental value approach," but rather to apportioning any value awarded from the value of the standard as a whole.

832013 WL 2111217 at 13 (internal citation omitted).

84 Id.

85 Id.

86 Id. at 19.
} 
the patents at issue that could have been adopted into the standard, and dividing that cost by the total number of infringing units to determine the maximum per unit royalty. Judge Holderman noted that the approach is based on the theory that a hypothetical licensee would not pay more for patents than the amount necessary to adopt an alternative. ${ }^{87}$ But Judge Holderman found that there were no alternatives to Innovatio's patents that would provide all of the functionality with respect to the 802.11 standard; he also pointed to Judge Robart's (at least partial) rejection of the incremental value approach. Instead, Judge Holderman adopted a "Top Down" approach, which generally starts with the average price of the identified royalty base (in Innovatio, a $\mathrm{WiFi}$ chip) and then calculates the average profit that the product/component maker earns on the sale of each unit, as a means of isolating the portion of the income from the sale of the product/component available to the maker to pay royalties on intellectual property. The available profit is then multiplied by a fraction calculated as a number of the SEPs at issue, divided by the total number of SEPs in the standard. ${ }^{88}$

\subsection{Economic discussion}

In our view, comparable licenses typically provide the best evidence of market value and thus should be central to any calculation methodology whenever possible. ${ }^{89}$ That said, when considering comparable licenses, it is important to consider factors specific to each license, such as the circumstances surrounding the bargaining, the timing, and the relative bargaining position of the parties. For example, a license entered when the commercial viability of the technology is still uncertain will, in general, result in a lower royalty than a license entered into when the commercial viability of the technology is already established or has increased. This latter point perhaps explains, at least in part, the seemingly unreasonably low royalty rates determined by the Shenzhen Intermediate People's Court (and affirmed by the Guangdong High People's Court) in Huawei v. InterDigital, where the court relied on pre-product release licenses but reportedly failed to account for differences in scope, time frame, or sales forecasts contemporaneous to negotiations. Public information indicates that the court relied on a 2007 license agreement with Apple, prior to Apple's introduction of the iPhone. Instead of using the negotiating parties' predicted sales for the covered products, the court used (ex post) actual sales to calculate an "effective" running royalty rate. Compared to contemporaneous industry analyst reports, iPhone sales far exceeded expectations, but it is the latter of which-the low volume sales expected at the time of negotiations-that would have formed the basis for the lump sum agreed upon. Using actual sales in this instancewhich were much higher than expected—will understate (and considerably so) the

\footnotetext{
87 Innovatio, 2013 WL 5593609 at 37.

88 Id. at 38.

89 Courtroom damages exercises are often far afield from normal course business negotiations, in particular, the former must rely on whatever data is available, even if it does not mirror real world discussions.
} 
implicit rate that the parties actually agreed to in determining the lump sum payment. Furthermore, the court failed to adjust any projections to present value.

The above endorsement of comparable licenses has intentionally left open the question of patent pools, as these deserve a discussion of their own. Given the difficulty of finding arm's length, market-based benchmarks for RAND rates and terms, it seems profligate to dismiss patent pools out of hand. However, Judge Holderman's discussion of the pitfalls that the use of patent pools can entail is important. Specifically, patent pools covering SEPs for a standard may be either "too high" (exceeding a RAND range) or "too low" (falling below a RAND range). For example, suppose the pool was formed by vertically integrated firms (i.e., covering multiple points in a manufacture-distribution chain) primarily interested in downstream profits. In forming the pool, these SEP holders may focus unduly on holding royalty expenses to a minimum (as they are an input cost). This could lead the pool rates to fall below a RAND range. Suppose, on the other hand, that the pool was formed by firms with low-value SEPs - technically essential but with minimal contribution to the standard. In this case, the risk is in the other direction: the pool contributors may be banding together in order to raise the pool rates above a RAND range. ${ }^{90}$ The commercial success of a given pool, from both the licensor and licensee sides, is a critical analysis element when deciding whether to use a pool as a RAND benchmark. Before using a pool's rates and terms as RAND benchmarks, the court (or experts) should ask the following questions:

(1) Has the pool signed up a significant number of SEP contributors and do those entities represent the key technology holders? If so, the pool's rates and terms are more likely to be high enough to fairly and reasonably compensate the SEP holders.

(2) Has the pool signed up a significant number of licensors and do these entities represent key standard implementers? If so, the pool's rates and terms are more likely to be sufficiently low enough to be fair and reasonable from implementers' perspectives.

If the answer to either question is no, then that pool is likely a poor FRAND benchmark. If a shortage of other useful benchmarks nevertheless pushes toward relying on the pool anyway, then it should be used with great caution and with full disclosure of its weaknesses and emphasis that it is an upper or lower bound on FRAND (as the case may be).

The last method seen in practice (thus far at least) is the incremental value rule approach. The underlying theory is well-established, based on decades of pricing theory for physical goods. And at a very general level, an incremental value approach both makes intuitive sense and also captures the $\mathrm{F}$ and $\mathrm{R}$ aspects of FRAND: a SEP holder should be compensated commensurate with the value its patented technology contributes to products compliant with the standard, in relation to other options the standard could have taken. The problem, however, is that

\footnotetext{
90 See, e.g., Anne Layne-Farrar \& Josh Lerner, To Join or Not to Join: Examining Patent Pool Participation and Rent Sharing Rules, “) 29 (2) InT'L. J. Industrial Org. 294-303 (2011).
} 
determining an "incremental" value for intangible intellectual property is quite difficult than the incremental cost for a physical good in a number of ways. First, as Judge Robart observed, two flaws in the approach are "its lack of real-world applicability" and "its impracticability with respect to implementation by courts."91 Second, the approach crucially depends on the point of comparison: incremental value as compared to what? The state of the art prior to any standard solution emerging, which is often the starting point for innovators? The price or value of the "next best alternative" competing for inclusion in the standard? This latter approach entails valuing two intangible contributions instead of one, so the workload is far higher (reinforcing Judge Robart's point of impracticability for courts). Moreover, technology selection within standard setting often involves multi-dimension tradeoffs between the options. In other words, the technologies often cannot be rank ordered from best to worst; different parties can have vastly different views of the relative merits of one option versus another. This complication makes any discussion of alternatives not only messy, but subjective. ${ }^{92}$ In short, while the incremental value rule can be a useful thought experiment, it is often not implementable in any form precise enough to guide specific FRAND determinations.

An important factor to consider regardless of the particular FRAND determination method followed is the actual FRAND commitment at issue. While policy and academic discussions often refer to "the FRAND commitment" as if it were a monolithic promise, there are in fact subtle, but important, differences across SDOs in regards to their IPR policies. For example, some organizations require members to sign contracts (membership agreements), while others simply require IPR declarations (such as letters of assurance). ${ }^{93}$ The definition of what is considered "essential" often varies too. Finally, the details included in the FRAND pledge requested, such as the requested geographic scope for the license, reciprocity in licensing, and the license duration, differ across organizations-sometimes dramatically so. ${ }^{94}$ The many differences in FRAND pledge terms can affect the hypothetical negotiation framework under the Georgia-Pacific approach, the acceptability of certain terms and conditions in comparable licenses, and can provide important context for any incremental value exercise attempted.

Lastly, in the case of an infringer who is engaged in holdup or holdout, enhanced damages may be appropriate and necessary to deter such conduct and adequately compensate the SEP holder. Indeed, if the worst penalty a SEP infringer faces is merely paying, after an adjudication, the FRAND royalty it should have agreed to pay when first asked, then holdup and holdout give implementers a profitable way to defer payment. As ALJ Essex explained, “[i]t makes good business sense, for as

\footnotetext{
91 Microsoft, 2013 WL 2111217 at *13 (internal citation omitted).

92 See Anne Layne-Farrar and Gerard Llobet, Moving Beyond Simple Examples: Assessing the Incremental Value Rule within Standards, 32 InT'L J. Industrial Org. 57-69 (2014).

93 See, e.g., Joanna Tsai \& Joshua D. Wright, Standard Setting, Intellectual Property Rights, and the Role of Antitrust in Regulating Incomplete Contracts, 80 ANTITRUST L.J. 1 (2015).

94 Anne Layne-Farrar, Proactive or Reactive? An Empirical Assessment of IPR Policy Revisions in the Wake of Antitrust Actions, 59 AnTITRust Bull. 373 (2014).
} 
long as they [infringers] hold out, they get the IPR for free, and in the end, they are counting on getting it at either no cost if they prevail on validity or infringement, or the price of a FRAND, the price they would have paid if they had followed the agreement in the first place." 95 This also puts SEP holders at a disadvantage that reduces the rewards to, and therefore discourages, both innovation and participation in standard setting. As Anne Layne-Farrar has explained:

Working backwards through a simple example illustrates th[e] point [that holdup can be a very attractive strategy for standards' implementers]. After litigation is concluded, if an implementer is found to infringe the asserted SEPs it will have to pay FRAND damages/royalties of F. But there is some chance (call it $\mathrm{p}$, where $0<\mathrm{p}<1$ ) that the court will decide the litigation in the implementer's favor, in which case it will pay nothing in damages. Abstracting from litigation expenses that both the plaintiff and the defendant must pay, on the eve of litigation the implementer's expected loss is only $\mathrm{p} \times \mathrm{F}$, which is clearly less than F. Stepping back even earlier in time, there is some chance (call it $\partial$, where $0<ð<1$ ) that the SEP holder will never file suit, say because it is focused on its downstream market or because it is worried about retaliation in other commercial dealings with the implementer. Thus, before the implementer ever makes its first investment in bringing standard-compliant products to market, it faces two options: 1) enter into a license with the SEP holder now and pay the FRAND royalty $F$ with certainty, or 2) practice patent holdout, which has the expected payout of $\partial \times \mathrm{p} \times \mathrm{F}$, an amount clearly lower than either $\mathrm{p} \times \mathrm{F}$ or $\mathrm{F}$. It would be entirely unsurprising for a significant number of implementers to choose option $2 .^{96}$

As such, awarding FRAND damages (as opposed to enhanced damages) for past infringement against an infringer who is engaged in holdup or holdout would likely be insufficient to deter such behavior.

\section{Choosing an appropriate base for FRAND royalty determinations}

Much attention has been given to the appropriate base for FRAND royalty determinations, namely whether a SEP holder may use the end-user device as the royalty base (which is common industry practice in the telecommunications sector, among others) or must use a smaller component such as a chipset as the royalty base. While the SSPPU approach was created by U.S. federal courts for use by juries in patent damages cases, it has recently been used by competition agencies in China (against Qualcomm) and India (against Ericsson) to investigate whether a

\footnotetext{
95 ALJ Essex Opinion, supra note 13, at 112.

96 Anne Layne-Farrar, Why Patent Holdout is Not Just a Fancy Name for Plain Old Patent Infringement, Competition Pol'y InT'L (Feb. 8, 2016), https://www.competitionpolicyinternational.com/why-patentholdout-is-not-just-a-fancy-name-for-plain-old-patent-infringement/.
} 
company's practice of charging royalties based on the end-user device prices amounts to "excessive" or "unfairly high" pricing. ${ }^{97}$

\subsection{Court rulings}

The U.S. Supreme Court long ago held that a patentee "must in every case give evidence tending to separate or apportion the defendant's profits and the patentee's damages between the patented feature and the unpatented features." 98 In the alternative, a patentee can show "that the profits and damages are to be calculated on the whole machine, for the reason that the entire value of the whole machine, as a marketable article, is properly and legally attributable to the patented feature." 99 This latter damages rule, known as the Entire Market Value Rule, was recently affirmed by the Federal Circuit, which ruled that "[a] patentee may assess damages based on the entire market value of the accused product only where the patented feature creates the basis for customer demand or substantially creates the value of the component parts." 100

On the other side of the spectrum, in LaserDynamics Inc. v. Quanta Computer USA, Inc., the Federal Circuit held that, "[w]here small elements of multicomponent products are accused of infringement, calculating a royalty on the entire product carries a considerable risk that the patentee will be improperly compensated for non-infringing components of that product. Thus, it is generally required that royalties be based not on the entire product, but instead on the "smallest salable patent-practicing unit." "101 The court went on to explain that " $[\mathrm{t}]$ the entire market value rule is a narrow exception to this general rule [of apportionment]. If it can be shown that the patented feature drives the demand for an entire multi-component product, a patentee may be awarded damages as a percentage of revenues or profits attributable to the entire product."102

The Federal Circuit in Ericsson reiterated its prior statements from LaserDynamics that the SSPPU was created as an evidentiary rule "to help our jury system reliably implement the substantive statutory requirement of apportionment of royalty damages to the invention's value." ${ }^{103}$ The court went on to explain that:

[1]ogically, an economist could do this [apportionment] in various ways-by careful selection of the royalty base to reflect the value added by the patented

\footnotetext{
97 See Douglas H. Ginsburg, Bruce H. Kobayashi, Koren W. Wong-Ervin \& Joshua D. Wright, Excessive Royalty Prohibitions and the Dangers of Punishing Vigorous Competition and Harming Incentives to Innovate, 4 Competition Policy InTERnAtional ANTITRust Chron. (2016), https://papers.ssrn.com/sol3/papers.cfm?abstract_id=2748252; Koren W. Wong-Ervin et. al., FRAND in India, forthcoming, ASHISH BHARDWAJ ET AL., Complications and Quandaries in the ICT Sector: Competition Issues and Standard Essential Patents, (2017).

98 Garretson v. Clark, 111 U.S. 120, 121 (1884).

99 Id.

100 Versata Software, Inc. v. SAP Am., Inc., 717 F.3d 1255, 1268 (Fed. Cir. 2013).

101694 F.3d 51, 67 (Fed. Cir. 2012).

102 Id.

103773 F.3d at 1226.
} 
feature, where that differentiation is possible; by adjustment of the royalty rate so as to discount the value of a product's non-patented features; or by a combination thereof. The essential requirement is that the ultimate reasonable royalty award must be based on the incremental value that the patented invention adds to the end product. ${ }^{104}$

As noted above, following Ericsson, the Federal Circuit in CISCO rejected the implementer's contention that all damages models must begin with the SSPPU approach, describing the position as "untenable."105

In cases with cross-jurisdictional references, a number of recent decisions involving Ericsson issued by the Delhi High Court held that the company's practice of charging royalties based on the price of the end-user device was consistent with RAND principles. ${ }^{106}$ The Delhi court cited decisions by the U.S. Court of Appeals for the Eastern District of Texas in CSIRO v. Cisco as well as China's National Development and Reform Commission in its investigation against Qualcomm. ${ }^{107}$

\subsection{Economic discussion}

The SSPPU approach was designed as a step towards mitigating the risk of juries awarding damages that reflect more than the value conveyed by use of the asserted patents. However, for some technologies, using the SSPPU as the royalty base is likely to go too far and may undervalue the technology. For example, although some technology may technically be implemented by a single component part, that technology may provide the end product more value than is captured in the component itself. Relying on the end-user product as the royalty base can help to

\footnotetext{
104 Id.

105809 F.3d 1295, 1303-1304.

106 In contrast, the Competition Commission of India (CCI) has brought several investigations against Ericsson, alleging that the company "seem[s] to be acting contrary to the FRAND terms by imposing royalties linked with cost of product of user for its patents." CCI Order under Section 26(1) of the Competition Act, 2002, In re: Micromax Informatics Ltd. v. Telefonaktiebolaget LM Ericsson 17 (Nov. 12, 2013), http://cci.gov.in/May2011/OrderOfCommission/261/502013.pdf; CCI Order under Section 26(1) of the Competition Act, 20, In re Intex Techn. Ltd., v. Telfonaktiebolaget LM Ericsson 17 (Jan. 16, 2014), http://cci.gov.in/May2011/OrderOfCommission/261/762013.pdf. Thus, "[f]or the use of GSM chip in a phone costing Rs 100, royalty would be Rs. 1.25 but if this GSM chip is used in a phone of Rs. 1000 , royalty would be Rs. 12.5." Id. According to the CCI, "[c] harging of two different license fees per unit phone for use of the same technology prima facie is discriminatory and also reflects excessive pricing vis-à-vis high cost phones." Id. For a summary of these decisions, see Koren W. Wong-Ervin, Standard Essential Patents: The International Landscape, Public Domain (ABA Section of Antitrust Law) (Spring 2014), https://papers.ssrn.com/sol3/papers.cfm?abstract_id=2668602.
}

107 Telefonaktiebolaget LM Ericsson v. Mercury Elecs., CS(OS) No. 442/2013, Order, High Court of Delhi [Del. H.C.], (Mar. 6, 2013), http://delhihighcourt.nic.in/dhcqrydisp_o.asp?pn=46519\&yr=2013; Telefonaktiebolaget LM Ericsson v Intex Techs. (India) Ltd., CS(OS) No. 1045/2014, Judgement, High Court of Delhi [Del. H.C.] 156 (Mar. 13, 2015), http://lobis.nic.in/ddir/dhc/MAN/judgement/16-032015/MAN13032015S10452014.pdf; Telefonaktiebolaget LM Ericsson v. Xiaomi Tech., CS(OS) 3775/2014, Judgment, High Court of Delhi [Del. H.C.] (Apr. 22, 2016), http://lobis.nic.in/ddir/dhc/ VKR/judgement/23-04-2016/VKR22042016S37752014.pdf; Telefonaktiebolaget LM Ericsson v. Lava Int'l. Ltd., CS(OS) No. 764/2015, Judgment, High Court of Delhi [Del. H.C.] 73 (June 10, 2016). 
internalize such externalities. As Judge Davis explained in the lower court decision in CSIRO v. Cisco:

Although it is largely undisputed that the inventive aspect of the '069 Patent is carried out in the PHY layer of the wireless chip, the chip itself is not the invention. The '069 Patent is a combination of techniques that largely solved the multipath problem for indoor wireless data communication. The benefit of the patent lies in the idea, not in the small amount of silicon that happens to be where that idea is physically implemented. Compounding this problem is the depression of chip prices in the damages period resulting from rampant infringement which occurred in the wireless industry. Prior to 2008, outside of the Radiata TLA, no company in the industry sought a license from CSIRO to the '069 Patent and CSIRO received no royalties whatsoever for that technology. It is simply illogical to attempt to value the contributions of the '069 Patent based on wireless chip prices that were artificially deflated because of pervasive infringement. Basing a royalty solely on chip price is like valuing a copyrighted book based only on the costs of the binding, paper, and ink needed to actually produce the physical product. While such a calculation captures the cost of the physical product, it provides no indication of its actual value. $^{108}$

Moreover, the value of a given SEP portfolio as realized by a licensee may also vary depending on the final product the licensee is focused on. For example, we would expect a given LTE SEP portfolio to deliver very different value to a mobile infrastructure manufacturer as compared to a handset maker as compared to a network operator.

With respect to wireless cellular technologies in particular, the licensed patents may read on the system or device level, rather than the component level. Indeed, many SEPs related to wireless cellular technologies incorporated in 2G, 3G, and 4G standards are designed to optimize the wireless system and network; their value therefore reaches well beyond a specific component in the device. One study that examined a representative sample of patents in a large portfolio of SEPs owned by Ericsson found that more than $80 \%$ of the SEPs read on the cellular network or the end device, not on an individual component. ${ }^{109}$

Courts need to be careful in the automatic application of component based royalties, instead taking the particular circumstances for the instant case into account. For multi-component products, calculating royalties on the entire product carries a risk that the patentee will be improperly compensated for non-infringing components of that product. On the other hand, if a small component does not adequately capture the value of the patented technology, but the patented technology is not the sole "driver" of end product demand, then the SEP holder could be caught between Charybdis and Scylla: using a small component will

\footnotetext{
108 CSIRO v. CISCO at 22 (E.D.Tex. July 23, 2014), http://www.essentialpatentblog.com/wp-content/ uploads/sites/64/2014/07/CSIRO-v.-Cisco.pdf.

109 Jonathan D. Putnam \& Tim A. Williams, The Smallest Salable Patent-Practicing Unit (SSPPU): Theory and Evidence at 41, tbl. 3 (Sept. 2016), https://ssrn.com/abstract=2835617.
} 
undercompensate the SEP holder unless a very large percentage rate is applied (something not yet seen in trials, and difficult to envision courts or juries accepting) but using the end product as the royalty base runs the very real risk of being thrown out as an attempt at holdup. ${ }^{110}$

As a matter of economics, it is the overall value assigned to the license that matters, and not its particular calculation method. Hence, a $1 \%$ rate applied to a $\$ 100$ end product yields the same royalty payment as a $10 \%$ rate applied to a $\$ 10$ component of that product. That being said, juries can be swayed by a relatively large end-product price and may view very small percentage rates as "unfair," but bench trials are likely to be well equipped to handle the pure mathematics.

In terms of overall welfare, Gerard Llobet and Jorge Padilla show that, compared to per unit component royalties, ad-valorem royalties based on the price of the enduser device tend to decrease the prices paid by consumers, particularly in the context of successive monopolies, which result in double-marginalization. Specifically, they find that " $[\mathrm{t}]$ he resulting price in the final market is never higher under ad-valorem royalties. The reason is that ad-valorem royalties are more similar to fixed fees than per-unit royalties. As a result, they make the double-marginalization problem less severe, generating lower distortions in the final market."111

Llobet and Padilla also conclude that ad-valorem rates tend to spur innovation. Such rates tend to benefit upstream producers without hurting downstream producers. When there are multiple upstream developers with complementary innovations, "numerical results indicate that ad-valorem royalties typically work better because by increasing upstream profits they generate a positive feedback on the incentive to innovate of all parties." 112

As a practical matter, most licenses in many high-tech markets, including smartphones, are negotiated on a patent portfolio basis using the end-user device as the royalty base. As a result, the strict application of the SSPPU method creates a tension between real-world practice and court decisions, ${ }^{113}$ as recognized by the U.S. Federal Circuit. It also renders most would-be comparable licenses noncomparable, or at least more difficult to translate.

We therefore conclude that courts should identify the appropriate royalty base as the one the parties most likely would have chosen in the hypothetical negotiation. This is necessarily a highly fact-specific issue that should be determined on a caseby-case basis.

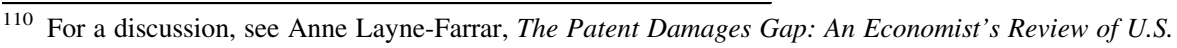
Statutory Patent Damages Apportionment Rules, https://papers.srn.com/sol3/ papers.cfm?abstract_id=2911289.

${ }^{111}$ Gerard Llobet \& Jorge Padilla, The Optimal Scope of the Royalty Base in Patent Licensing 5 (Jun. 25, 2014), https://papers.ssrn.com/sol3/papers.cfm?abstract_id=2417216.

${ }^{112} I d$. at 6-7.

113 The tension between portfolio licensing in practice and individual SEP licensing in some courts is yet another problem area.
} 


\section{Worldwide portfolio licensing as consistent with FRAND-assurances}

\subsection{Court rulings}

A component of the methodology used to calculate FRAND royalties and damages is what, exactly, to include in the court-determined license. It is common industry practice to license patents, including FRAND-assured SEPs, on a worldwide portfolio basis. Courts have differed on their willingness to assess FRAND for a portfolio versus a handful of specifically asserted patents. For instance, early cases in the Netherlands determined FRAND rates for the Netherland subset of SEPs only. ${ }^{114}$

The trend, however, appears to be toward finding global portfolio licensing practices as consistent with FRAND-assurances.

For example, in St Lawrence vs. Vodafone, a German court upheld the use of worldwide portfolio licensing on the grounds that it was efficient and avoided an evasion of the "nondiscriminatory" prong of FRAND. The court in that case also held that the implementer's counteroffer was not FRAND on the grounds that it was limited to Germany. Specifically, the court stated that a patentee not only has a "legitimate interest to settle all acts of use" by a single license agreement rather than on a patent-by-patent basis around the world, but would "incur high costs," including transaction and monitoring costs, if forced to license its portfolio "in diverse agreements (for a plurality of patents and a plurality of countries)." "115 The court also noted that reaching a worldwide portfolio license agreement is common industry practice in the mobile industry. ${ }^{116}$

Similarly, in Unwired Planet, the UK court concluded that, based on the totality of the evidence, "multijurisdictional portfolio licences themselves are unlikely to have inherently anti-competitive effects and that a demand for a worldwide licence is not inherently likely to distort competition... . Assuming the licensor has a worldwide portfolio of SEPs, in my judgment asking a licensee to accept a worldwide licence is unlikely to be abusive." 117 Observe that the UK court determined that a "worldwide portfolio" need not include patents in every country of interest, just a sufficiently large number of them. The court went on to say that, while " $[\mathrm{t}]$ here was a suggestion that a worldwide licence might create a disincentive to challenge the validity of patents in other jurisdictions, "[a] similar disincentive applies to any portfolio licence," and thus "[i]t is a factor to take into account but

\footnotetext{
114 See, e.g., Samsung v. Apple, ECLI:NL:RBSGR:2011:BT7610, Netherlands, The Hague District Court, 14 Oct. 2011, http://www.eplawpatentblog.com/2011/October/Samsung_Apple\%20_EN_.pdf.

115 LG Düsseldorf, St. Lawrence v. Vodafone 4a O 73/14.

116 Id. Similarly, in Pioneer v. Acer, the Manheim Regional Court concluded that if the original offer was worldwide, and the infringer sells products in other European countries, a counteroffer that only covers Germany and the patent in suit does not comply with the usual practice in the industry and therefore is not considered FRAND. This case was reversed on other grounds by the Higher Regional Court, http:// ljournal.ru/wp-content/uploads/2016/08/d-2016-154.pdf. (2016).

117 Unwired Planet Int'l Ltd v. Huawei Tech. Co. Ltd [2017] EWHC 711 (Pat) 9 535, https:// www.judiciary.gov.uk/wp-content/uploads/2017/04/unwired-planet-v-huawei-20170405.pdf.
} 
not enough on its own to make a portfolio licence (worldwide or national) inherently anti-competitive." 118

\subsection{Economic discussion}

From a legal point of view, it is true that patents are country-specific rights granted by the country's government. From an economic point of view, however, unless a standard is limited to a particular nation (a relatively uncommon occurrence in the modern economy), it is difficult to justify a country-by-country approach to FRAND licensing determinations. The courts appear to be leaning toward the more economic, efficient approach of treating SEP portfolios as global units-an approach we endorse.

While we find the global portfolio approach to be far more sensible-not to mention more fair, reasonable, and non-discriminatory-the tension between legal boundaries and economic rationality implies that one or the other view must be compromised to some extent in any judicial ruling. In particular, by recognizing the market-based efficiency of making FRAND determinations on a global SEP portfolio basis, courts must reach beyond their own borders in extra-jurisdictional decisions. This reach can be limited in sensible ways with rulings focusing on local patents, local production, and/or local sales of infringing products, along with avoiding setting terms and conditions for foreign patents covering only foreign sales.

A second complication arises in the United States with the dichotomy between breach of contract RAND cases filed by licensees (namely, Microsoft v. Motorola), and patent infringement cases filed by SEP holders (e.g. Ericsson v. D-Link). In the former type of case, the contract covers all SEPs for the standard at issue and so must be considered on a global portfolio basis. In the latter circumstance, however, patent infringement cases involve in-depth reviews of patent claims, validity issues, and infringement evidence. This level of detail is impractical on a portfolio basis, leaving courts in a quandary over FRAND determinations. One way to reconcile the common sense of global SEP FRAND rates and terms with the specificity of patent infringement cases would be to take a handful of SEPs as representative, with the detailed court assessment focusing on these, but the rates and terms then set for the portfolio as a whole. This is, in fact, a common tactic in arms' length license negotiations, and is essentially what the Beijing Intellectual Property Court did in the Sony case discussed above.

\section{Conclusion}

Based on the case law to date, there appear to be global consensus emerging on certain issues, namely, that concerns about patent holdup are symmetrical and that relying on comparable licenses (when available) is important, with comparables including licenses based on the end-user device.

${ }^{118}$ Id. 9536. 
In the United States, the Federal Circuit's decisions in Ericsson and CISCO reject much of the approach previously taken by U.S. district courts, holding instead that concerns about holdup and royalty stacking must be proven and not theoretical, explaining that "[t]here is no Georgia-Pacific-like list of factors that district courts can parrot" for every RAND case, and clarifying that the SSPPU is an evidentiary rule designed to assist juries and is therefore not necessary in bench trials or arm's length negotiations. While the U.S. Ninth Circuit affirmed Judge Robart's decision in Microsoft, that decision has limited precedential value, particularly given that the court found that Motorola had waived virtually all issues it raised on appeal. To the extent that the decision differs from the Federal Circuit's decisions, it is the latter that govern patent law disputes throughout the United States. ${ }^{119}$

In Europe, member states continue to flesh out the landmark decision from the ECJ in Huawei, providing further guidance to SEP holders seeking to take advantage of the court's safe harbor from competition law liability for seeking or enforcing injunctive relief on FRAND-assured SEPs.

With respect to injunctive relief, courts in India, China, and the UK have granted such relief on FRAND-assured SEPs, when needed to avoid holdout by implementers.

Acknowledgements The authors thank David Long, Georg Nolte, Su Sun, Eric Stasik, and Judge Zhu Li for their valuable comments, and Emile Khattar and Wesley Davis for their research assistance. The views expressed here are the authors own and do not necessarily reflect the views of any of their affiliations. This article updates and builds on our prior articles, Methodologies for Calculating FRAND Damages and An Analysis of the Federal Circuit's Decision in Ericsson v. D-Link, Competition Policy International Antitrust Chronicle (March 2015).

Open Access This article is distributed under the terms of the Creative Commons Attribution 4.0 International License (http://creativecommons.org/licenses/by/4.0/), which permits unrestricted use, distribution, and reproduction in any medium, provided you give appropriate credit to the original author(s) and the source, provide a link to the Creative Commons license, and indicate if changes were made.

\footnotetext{
${ }^{119}$ We do not suggest that contract law is not a desirable means to resolve FRAND disputes. Indeed, in comparison with antitrust law sanctions, it may be a superior vehicle for resolving FRAND disputes to the extent that contract law is sufficient to provide optimal deterrence and antitrust sanctions may result in overdeterence. See, e.g., Ginsburg et al., supra note 4, at 3.
} 